\title{
The attitudes of parents and children towards restoration of deciduous molar teeth with stainless steel crown (SSC) in the Dental Hospital University of Baiturrahmah
}

\author{
Sri P. Utami, ${ }^{*}$ Hanifa U. Dwi, Hamdy Lisfriza
}

Department of Pediatric, Faculty of Dentistry, University of Baiturrahmah, Padang, Indonesia
*Correspondence to: Sri P. Utami, Department of Pediatric, Faculty of Dentistry, University of Baiturrahmah, Padang, Indonesia panduutamidrg@yahoo.co.id

Received: 3 0ctober 2019 Revised: 28 February 2020 Accepted: 28 March 2020 Available Online: 1 April 2020

Keywords: Children, Level of satisfaction, Parents, Stainless steel crowns

Cite this Article: Utami SP, Dwi HU, Lisfriza H. 2020. The attitudes of parents and children towards restoration of deciduous molar teeth with stainless steel crown (SSC) in the Dental Hospital University of Baiturrahmah. Journal of Dentomaxillofacial Science 5(1): 52-55. D0I: 10.15562/ jdmfs.v5i1.994

\section{Introduction}

Caries is an infectious disease of the results of the interaction of various factors including bacteria on the surface of the teeth, plaque or biofilm, and diet resulting in damage to the structure or constituent layers of the tooth. Dietary component in question in particular are carbohydrates or sugars that can later be fermented by plaque bacteria into acid, especially lactic and acetic acids, causing demineralization of dental hard tissues that require sufficient time to occurrence of caries in primary teeth. ${ }^{1}$ Carries on posterior of primary teeth is higher than other teeth, this problem is common in children of school age. The causes include excessive sugar consumption, food lodged between teeth, and a lack of maintenance is not a regular toothbrush. Caries on posterior teeth which extends up to pulp chamber which interferes with the function of mastication and cause the pain that need treatment to maintain primary teeth to be replaced by permanent teeth. ${ }^{2}$

The World Health Organization (WHO) in 2007 states that the prevalence of dental caries in children increased up to $60-90 \%$, while according to data from Indonesian Dentists Association (PDGI)
Results: In general, children's attitude scores were positive, and the average attitude 0btained score was 10:17 \pm 1:05, 97.5\% of children Obtained good attitudes. Also Parental attitude scores are positive; Reviews their attitudes on average were Obtained to be $14.95 \pm 1.9$, $95 \%$ of parents rated good attitude.

Conclusion:The attitude towards SSC scores of children are good and do not depend on age, gender. Almost all parents are satisfied with the presentation, the agreed by them about the children, they receive the crown well. at least $89 \%$ of the patients are children caries. Based on the results of health research characteristics, the prevalence of dental caries in children aged 3-5 years $81.7 \%$. While the prevalence of dental caries by age group was $60 \%$ at 3 years, $85 \%$ at 4 years and $86.4 \%$ at 5 years of age. But parents still consider decay in primary teeth is not a problem because the deciduous teeth only temporary, to be replaced by permanent teeth. ${ }^{3}$

Stainless steel crown (SSC) is a medication or treatment is very useful in pediatric patients because of a restorative material that is ideal for preventing the loss of decidui teeth prematurely. SSC is widely used on deciduous molars after endodontic treatment. Other common indications include dental care hypoplastik, multiple caries, tooth fracture, as the handle of a space maintainer or prostheses etc. It is also useful in conditions of bruxism and tooth anterior cross bites. ${ }^{4,5}$ SSC is a matter of the restoration of choice in the treatment of primary teeth with extensive tooth decay because it can cover the entire crown of the tooth and tooth reshaping the anatomical shape and more durable than other restoration. In pediatric dentistry, 
implementation of SSC to provide care efficiently and simultaneously reducing operating time / action because it works faster, because the crown SSC has provided in accordance with the size and shape of the teeth. ${ }^{6}$ In fact, compared with other restoration methods, placement SSC less intrusive for the patient as well as more durable because it is made of logam. Despite the high success rate in protecting teeth, restorations have the disadvantage to fulfill the aesthetic demands of patients and the parents because of the color of the crown does not match the original tooth. Aesthetic is a very important part in human life because it can affect the quality of life of patients. The main purpose in dental treatment and oral care is to assist the patient in order to achieve the level of satisfaction of the teeth and mouth. ${ }^{7}$ The assessment on the expectations of the patient is very important in understanding the oral health, patient satisfaction with treatment, and ultimately provide the overall perception of the quality of the health system. ${ }^{8}$

Satisfaction of parents lead a fundamental role in health care especially those of children's oral health. Aesthetically, the parents may not approve a treatment plan that will be done later. Children must agree or follow with their parents choice in determining treatment plans exist. Therefore, the dentist can reduce their fears by explaining the benefits of SSC as well as possible. This study aims to examine the attitudes of parents and children towards the restoration of deciduous molars with stainless steel crowns (Stainless Steel Crown / SSC) at the Dental Hospital of Baiturrahmah University.

\section{Material and Methods}

This research is a quantitative research method is analytic. The approach used cross sectional conducted in In July - August, 2019 at Department of Pediatric in Dental Hospital University of Baiturrahmah.

The number of samples are 40 children where the sample is collected based on inclusion and exclusion criteria. Inclusion criteria were patients who wore the crown of Stainless Steel during the last 3-6 months, consisting of children aged 4-6 years, have criteria for mental and physical health, have at least one treatment SSC for deciduous molar teeth, and patients who do not have a history of systemic disease. Exclusion criteria were patients who refused to be involved in this study, uncooperative patients and patients who do not seek treatment at the Dental Hospital University of Baiturrahmah.

Criteria for assessment using self-report questionnaires centered on children and the elderly are valid filled with 11 questions consisting of 6 questions for children and 5 questions for parents, Processing and data analysisusing t-test at the significant level of $\mathrm{p}<0.05$.

\section{Results}

Forty questionnaires were filled in full (percentage of responses: $100 \%)$. The average age of participants is 7 years $47.5 \%$ ( 23 women and 19 men). The majority of mother $(\mathrm{n}=23,57.5 \%)$ were housewives and fathers $(\mathrm{n}=17,42.5 \%)$ were entrepreneur. The average score of the attitudes of parents and children are not significant based on sex $(\mathrm{p}=0.134, \mathrm{p}=0.525)$ table 1 . The children mean attitudes score is 10.17 , parents average score of attitude is 15 . The highest of children's attitude is 12 , while the parents is 19 .

Children's responses; most of the children $(\mathrm{n}=$ $38,95 \%)$ liked the look of their iron teeth, but the minority $(\mathrm{n}=1,2.5 \%)$ did not know and did not like; most of the children $(n=38,95 \%)$ happy with their iron teeth but $(n=1,2,5 \%)$ did not know and was not pleased; most of the children $(n=39$, 97.5\%) like iron teeth install sessions; all children $(\mathrm{n}=40,100 \%)$ stated that the dentist is friendly to them; nearly half of the children $(n=28,70 \%)$ do not mind being questioned about their iron teeth; most of the children $(\mathrm{n}=38,95 \%)$ liked the metal crown, once fitted on their teeth.

Response parents; only half of parents $(n=23$, $53.5 \%)$ liked the appearance of metal crowns of their children; the majority $(n=37,92.5 \%)$ think that their children accepted the metal crown well (agree or strongly agree); almost $(n=37,92.5 \%)$ who strongly agree or agree that metal crowns does not interfere with permanent dentition; all parents $(\mathrm{n}=40,100 \%)$ strongly agree or agree that the team

\begin{tabular}{lcccc} 
Table 1 & $\begin{array}{l}\text { Attitude (mean and standard deviation) of parents and children todeciduous molar } \\
\text { tooth restoration with a stainless steel crown by sex }\end{array}$ \\
\hline Attitude & Gender & $\boldsymbol{N}$ & Mean \pm SD & $\boldsymbol{p}$ \\
\hline child & Male & 17 & $9.95 \pm 1.02$ & 0.134 \\
& woman & 23 & $10.42 \pm 1.07$ & 0.525 \\
Parents & Male & 17 & $14.82 \pm 1.8$ & \pm 2.09 \\
& woman & 23 & & \\
\hline
\end{tabular}


Table 2 Children's responses responding to questions about attitudes and experiences stainless steel crown

\begin{tabular}{|c|c|c|c|}
\hline \multirow[b]{2}{*}{ Question attitude child } & \multicolumn{3}{|c|}{ attitudes of children } \\
\hline & $\begin{array}{c}\text { Yes } \\
\text { n (\%) }\end{array}$ & Do not know n (\%) & $\begin{array}{c}\text { No } \\
\text { n (\%) }\end{array}$ \\
\hline Do you like shape iron teeth & $38(95 \%)$ & $1(2.5 \%)$ & $1(2.5 \%)$ \\
\hline Are you happy with iron teeth & $38(95 \%)$ & $1(2.5 \%)$ & $1(2.5 \%)$ \\
\hline What you like iron teeth install sessions & $39(97.5 \%)$ & $1(2.5 \%)$ & $0(0 \%)$ \\
\hline Do you mind asked about your iron teeth & $6(15 \%)$ & $6(15 \%)$ & $28(70 \%)$ \\
\hline Does the dentist friendly & $40(100 \%)$ & $0(0 \%)$ & $0(0 \%)$ \\
\hline if you like your iron teeth immediately after a tooth is installed & $38(95 \%)$ & $2(5 \%)$ & $0(0 \%)$ \\
\hline
\end{tabular}

\section{Table 3 The response of parents to the question about the attitude of the stainless steel crown preformed for their} children

\begin{tabular}{|c|c|c|c|c|c|}
\hline \multirow[b]{2}{*}{ Question attitude of parents } & \multicolumn{5}{|c|}{ The attitude of parents } \\
\hline & $\begin{array}{c}\text { Strongly agree } \\
\text { n (\%) }\end{array}$ & Agree n (\%) & $\begin{array}{l}\text { Neutral } \\
\text { n (\%) }\end{array}$ & $\begin{array}{c}\text { Disagree } \\
\text { n (\%) }\end{array}$ & $\begin{array}{c}\text { Strongly disagree } \\
\text { n (\%) }\end{array}$ \\
\hline I do not love my child's metal crown & $0(0 \%)$ & $6(15 \%)$ & $9(22.5 \%)$ & $23(57.5 \%)$ & $2(5 \%)$ \\
\hline My child accepted the iron teeth & $18(45 \%)$ & $19(47.5)$ & $3(7.5)$ & $0(0 \%)$ & $0(0 \%)$ \\
\hline The treatment does not interfere permanent dentition & $16(40 \%)$ & $21(52.5)$ & $2(5 \%)$ & $1(2.5)$ & $0(0 \%)$ \\
\hline $\begin{array}{l}\text { The medical team when dealing with my child was } \\
\text { friendly }\end{array}$ & $19(47.5)$ & $21(52.5)$ & $0(0 \%)$ & $0(0 \%)$ & $0(0 \%)$ \\
\hline Iron teeth is safe for dental health or my child's body & $15(37.5)$ & $23(57.5)$ & $2(5 \%)$ & $0(0 \%)$ & $0(0 \%)$ \\
\hline
\end{tabular}

Table 4 Scores attitudes of children and parents

\begin{tabular}{|c|c|c|c|c|c|c|}
\hline \multirow[b]{2}{*}{ Scores Attitude } & \multicolumn{3}{|c|}{ Child (0-12) } & \multicolumn{3}{|c|}{ Parents $(0-20)$} \\
\hline & $0-3$ negative & 4-7 neutral & 8-12 positive & 0-5 negative & 6-12 neutral & positive $13-20$ \\
\hline Score $(\%)$ & $0(0 \%)$ & $1(2.5 \%)$ & $39(97.5 \%)$ & $0(0 \%)$ & $2(5 \%)$ & $38(95 \%)$ \\
\hline Min & & 6 & & & 11 & \\
\hline Max & & 12 & & & 19 & \\
\hline Mean \pm SD & & $10.17 \pm 1.05$ & & & $14.95 \pm 1.9$ & \\
\hline
\end{tabular}

has been friendly when taking care of their child's teeth; almost ( $\mathrm{n}=38,95 \%)$ strongly agree or agree that secure the metal crowns for dental health or the child's body.

In general, a score of children's attitudes are positive, and the average score obtained attitude be $10.17 \pm 1.05,97.5 \%$ of children scored a good attitude. Scores of parents are also positive attitude; Average attitude they acquired be $14.95 \pm 1.9,95 \%$ of parents scored a good attitude table 2, table 3 and table 4

\section{Discussion}

The results showed that overall scores of children's attitude towards recovery deciduous molars with good SSC. Scores of children towards appearance and acceptance of the crown, the relationship with the dentist, and experience in the treatment procedure crown installation session, is good.

Nearly half of the children do not mind being questioned about their iron teeth. Almost all of the parents are satisfied with the appearance of a crown. Nevertheless, the majority of parents reported that their children accepted the crown. Parents think treatment using SSC does not interfere with the growth of permanent teeth. The relationship between the dentist and the patient regarding the efficiency of the crown, there is a good attitude. It was concluded that the SSC function should be better explained to the parents hence the trust between the parents and the dentist still remain.

The average score of the attitude of children and parents do not significantly based on sex. This shows that there is no connection with the sex of children and parents attitude. The majority of 
parents whose children treated with SSC work as housewives and entrepreneur.

Based on research by Zimmerman et al on the attitude of parents towards materials and methods used for the teeth of their children, it is recommended that the main concern and reluctance of parents to restore primary molars of their children are due to four main reasons as follows: aesthetic features, costs, toxicity and durability. In this study clarified that the majority of parents worried about the SSC due to uncertainty of aesthetic and cost. Finally, it is clear that parents in the economic and social position of the higher complain more about the amalgam used in dental office, while the SSC is less favorable for aesthetic and cost; also clear that $43 \%$ of dentists respect the opinions of parents and their ideas before the dentist's opinion. ${ }^{9}$

Children's attitudes towards SSC for primary molars, it is suggested that almost $90 \%$ of children who receive care are satisfied with the crown. However, there was no significant difference between sex, age, and condition of the parents, which is consistent with our results. ${ }^{10}$

The majority of participants in the study received the clinical process of care and the kids think good treatment sessions. The results are important because some parents, even some dentists, think children cannot tolerate the treatment SSC and it is considered as a barrier. ${ }^{11}$

One finding from this study is that most children do not worry about the appearance of the crown. However, the parents are satisfied with the appearance of the crown (like research Zimmerman et al.) That can be caused by the fact that children who participated in our study were an average age of 7 years, and the crown gives children a special appearance even can be a privilege. Individually, as an adult or juvenile, a person generally like normal looking appearance and does not like SSC. This study asked children about the appearance of the SSC, but they showed a picture of alternatives such as composite restorations to the patient. In general, it seems to make a good relationship between children and their parents and explain the efficiency, functionality, and the importance of the crown makes them accept and have a good attitude. ${ }^{12}$

\section{Conclusion}

In general, the score of children's attitudes towards restoration of deciduous molars with SSC are good and does not depend on age, sex, occupation. Besides, parents are satisfied with the placement of crowns, the majority of them reported that their children have received the crown well. Therefore. The attitudes of children and parents towards the restoration of deciduous molars with stainless steel crowns showed good attitude and accept the treatment.

\section{Acknowledgment}

Thank you very much for the Department Pediatric, Faculty of Dentistry, University of Baiturrahmah Padang for allowing this research.

\section{Conflict of Interest}

The authors report no conflict of interest.

\section{References}

1. Hartman, Henry. Effectiveness of vital pulpotomy in one visit on deciduous teeth. J Med $\backslash$ Health 2018;2: 691. (In Indonesia)

2. Basuni, Cholil, Deby K. Overview of oral hygiene index based on community education level in Guntung Ujung Village, Banjar Regency. Dentino L Kedokteran Gigi 2014;2: 18-23. (In Indonesia)

3. McDonald RE, Avery DR, Dean JA. Resorative dentistry. In: McDonald RE, ed. Dentistry for the child and adolescent. 9th ed. Missouri: Mosby Inc.; 2011. p. 333339.

4. Humphrey WP. Use of chrome steel in children's dentistry. Dent Surv 1950;26: 945947.

5. Ramazani N, Mohammadi A, Amirabadi F, et al. In vitro investigation of the cleaning efficacy, shaping ability, preparation time and file deformation of continuous rotary, reciprocating ro-tary and manual instrumentations in primary molars. J Dent Res Dent Clin Dent Prospects 2016;10: 49-56.

6. Anas ASS, Abdullah AZ. Study of service quality based on patient satisfaction at the Public Hospital Dr. Wahidin Sudirohusodo Makassar. J Dentomaxillofac Sci 2008;7: 99-106.

7. Rasool G. Orthodontic treatment and patient's expectations. POJ 2012;4: 44-47.

8. Zimmerman JA, Feigal RJ, Till MJ, et al. Parental attitudes on restorative materials as factors influencing current use in pediatric dentistry. Pediatr Dent 2009;31: 63-70.

9. Page LA, Boyd DH, Davidson SE, et al. Acceptability of the Hall Technique to parents and children. N Z Dent J 2014;110: 12-17.

10. Bell SJ, Morgan AG, Marshman Z, et al. Child and parental acceptance of preformed metal crowns. Eur Arch Paediatr Dent 2010;11: 218-224.

11. Najmeh A, Maryam H, Golbidi M. Attitudes of parents and children toward primary molars restoration with stainless steel crown. Contem Clin Dentist 2017;8: 421-426.

12. Newsome PR, McGrath C. Patient-centered measures in dental practice: patient satisfaction. Dent Update 2007;34: 87-88.

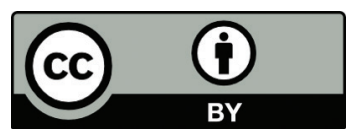

This work is licensed under a Creative Commons Attribution 